\title{
Induction of heat tolerance in tomato cultivar with heat tolerant bacteria under field condition
}

\begin{abstract}
Tehmeena Mukhtar ${ }^{1}$, Shafiq-ur-Rehman ${ }^{2 *}$, Tariq Sultan ${ }^{3}$, Farooq Hussain Munis ${ }^{1}$, Hassan Javed Chaudhary ${ }^{1^{* *}}$ ${ }^{1}$ Department of Plant Sciences, Quaid-i-Azam University, Islamabad 45320, Pakistan

${ }^{2}$ Department of Botany, University of Okara, Okara 56300, Pakistan

${ }^{3}$ Land Resource Research Institute, NARC, Islamabad 44000, Pakistan

Received:

March 29, 2021

Accepted:

September 07, 2021

Online First:

November 03, 2021

Published:

February 28, 2022

\section{Abstract}

Two planned studies (Isolation, characterization, and field studies) were piloted to assess the potential of heat-tolerant plant growth promoting bacteria (PGPB) to mitigate heat stress in the tomato plant. . The production of indole acetic acid (IAA), phosphate, solubilization and ammonia, as well as siderophores, hydrogen cyanide $(\mathrm{HCN})$, extracellular enzyme activity (protease, amylase, pectinase, and catalase), ACC-deaminase, and exopolysaccharide synthesis, were all positively confirmed in the isolate. The selected strain was screened at high temperature of $60{ }^{0} \mathrm{C}$. The promising potential heat-tolerant isolate was further identified through 16S rRNA gene sequencing technique and $A c d s$ gene was also successfully amplified. Morphological characterization revealed that strain was Gram positive. B. safensis (T6) strain showed higher quantity of Gibberellic acid $(8.73 \mu \mathrm{g} / \mathrm{ml})$ and Kinetin $(34.8$ $\mu \mathrm{g} / \mathrm{ml})$ under heat stress condition. The results of morpho-physiological parameters revealed significant effects of heat on un-inoculated and inoculated tomato plants under high temperature stress. Multi-year/multi-location field trials were done to extend studies of heat mitigation effects after encouraging results by bacterial strains. Plant growth promoting bacteria (PGPB) improved agronomic and yield metrics of tomato plants under heat stress in all field studies. First year 2018 \& 2019 field trials at National Agriculture Research Centre, Islamabad, Pakistan showed that Bacillus safensis (T6) produced the maximum number of flower's $(40.7 \%)$ and fruits $(24.8 \%)$ in 2018 and number of flowers $(43$ 1\%) and fruits (11.03\%) in 2019 while the consortia treatments produced maximum flowers (16.9\%) and fruits $(52.1 \%)$, respectively. The current study comprehensively exhibited the role of PGPB in the mitigation of heat stress.
\end{abstract}

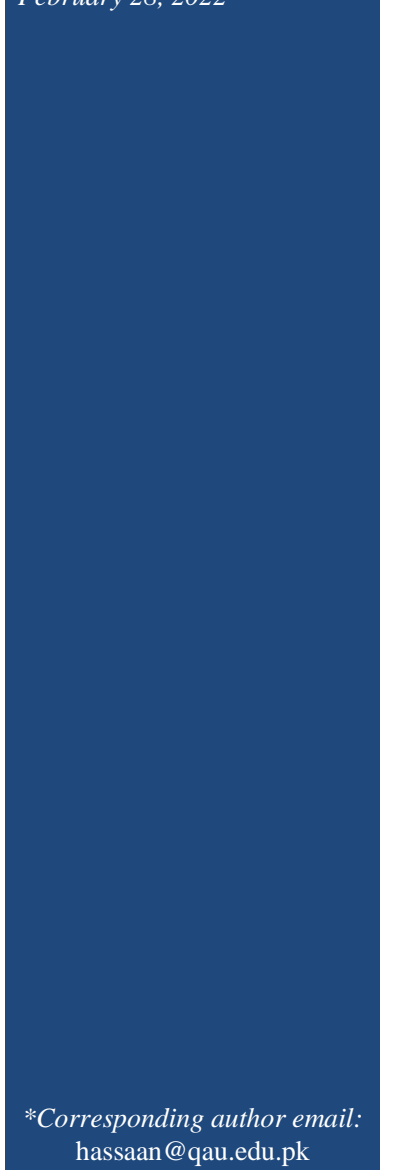

Keywords: Microorganisms, PGPB, growth regulators, thermo-tolerance

\section{How to cite this:}

Mukhtar T, Rehman SU, Sultan T, Munis FH and Chaudhary HJ, 2022. Induction of heat tolerance in tomato cultivar with heat tolerant bacteria under field condition. Asian J. Agric. Biol. 2022(2): 202103112. DOI: https://doi.org/10.35495/ajab.2021.03.112

This is an Open Access article distributed under the terms of the Creative Commons Attribution 3.0 License. (https://creativecommons.org/licenses/by/3.0), which permits unrestricted use, distribution, and reproduction in any medium, provided the original work is properly cited. 


\section{Introduction}

Heat stress is a type of environmental stress defined by the temperature range, severity, and duration of the heat (Grover et al., 2011). Abiotic stress, such as high temperatures, can result in economic yield losses when they exceed a certain threshold (Ruelland and Zachowski, 2010). According to numerous studies and crop modelling methodologies, global temperature is anticipated to rise by the end of the twenty-first century (2081-2100). Even though temperature increase may be beneficial in some areas, crop production declines are probable unless adaptive strategies are used (Bita and Gerats, 2013). Heat stress has a significant impact on plant growth and development due to morphological and physiological changes. The first affected stage during plant growth is the germination stage. Abnormal growth of seedling, vigor, stunted radicle and plumule growth during initial stages are the responses of the plant under heat stress conditions. Sometime under unusual and abrupt temperature rise, the size and area of leaves may reduce, and it may lead to fall of the young leaves. This influences the photosynthetic efficiency of the plant (Greer and Weedon, 2011). High-temperature stress conditions are also indicated by sunburns and blistering of leaves, branches, and stems. Leaf abscission, senescence, stunted roots, shoot growth, fruit destruction, and decreased pigmentation are the most common concerns during heat stress. Heat stress affects almost all tissues of the plant at all stages; however, the reproductive tissues and organs are the most sensitive. Even heat spell of a short duration may result in damage of new floral buds and cause fruit abortion as well. Heat stress adversely affects fertilization process, germination of pollen, tube growth of pollen, viability of ovule, stigma and style positions of the flower, no flower production, poor pollination, the growth of the endosperm and poor fruit set (Grover et al., 2011).

The tomato (Solanum lycopersicum) is a member of the Solanaceae family that originated in South America and was introduced to Europe (Bauchet and Causse, 2012). Tomatoes are high in antioxidants such as flavonoids and phenolics, as well as vitamins, minerals, dietary fibers, and carotenoids, which are important nutraceutical molecules. Tomato, being eaten either raw or in number of other cooked forms, has become part of our daily diet. Globally the annual production of tomatoes is about 159 million tonnes (http://www.agricorner.com). In Pakistan two crops of tomato are produced per year one in summer and second in autumn thus tomato is available throughout the year (Noonari et al., 2018). Baluchistan was the largest tomato producing province with production of 200 thousand tones planted an area of 27 thousand hectares, followed by Sindh, Khyber Pakhtunkhwa, and Punjab. Pakistan produces 4.2 million tonnes of tomato annually with a total cultivated area of more than 65 thousand hectares. More than $70 \%$ losses in harvesting of cultivated tomato crops have been reported because of hot summer season of many agricultural regions (Fahad et al., 2017).

Today's modern technologies such as genetic, biotechnological, and transgenic technologies have been developed to cope with heat stress issue. The thermo-resistant plants change the heat shock protein level in their body to regulate heat stress issue through heat shock proteins (HSPs). Advanced genetic editing and transformation along with techniques of engineering soluble metabolites like antioxidants and integral expression of HSPs have proved as key tools in conferring heat tolerance in tomato crops. Almost all the currently used heat tolerance solutions are both expensive and site-specific. Furthermore, conferring microbial relationships with plants to minimize abiotic challenges such as high temperature is being used in agriculture as a viable and less expensive strategy. Such microbes are called as plant growth-promoting bacteria (PGPB) that not only mitigate environmental stresses, but also enhance growth and yield of plants (Mukhtar et al., 2020b).

Plant growth is aided by symbiotic rhizo-bacterial strains through a variety of methods, including phosphorus and potassium solubilization, nitrogen fixation, and nodulation, among others. Plant growth promoting strains from a variety of taxa have been found so far, with Bacillus and Pseudomonas being the most investigated (Ahmad et al., 2018). Besides these stresses, PGPBs have also been tested for their ability to mitigate temperature stress in some other crops (Nadeem et al., 2014). The present investigation was undertaken to assess the ability of thermo-tolerant bacteria to enhance yield of tomato crop including different physiological parameters under both green house as well as field conditions.

\section{Material and Methods}

\section{Soil, plants sampling and isolation of rhizobacteria}

Soil and plant samples were collected in triplicates 
from Larkana, Sindh Province, Pakistan $\left(27.5570^{\circ} \mathrm{N}\right.$, $68.2028^{\circ}$ E). Leaves stem and roots from each collected plant sample were separated and kept in sterilized plastic bags. The samples were carefully transported to Plant Microbe Interactions Lab, Department of Plant Sciences, Quaid-i-Azam University, Islamabad, Pakistan and stored in a refrigerator at $4^{\circ} \mathrm{C}$ for further analyses. The dilution plate method was used for isolation of bacteria from samples (Amna et al., 2019).

\section{Plant growth promoting potential of heat tolerant strains \\ Indole acetic acid (IAA)}

Falcon tubes containing Luria Bertani (LB) broth that was amended with tryptophan (precursor of IAA) were used for the growth of bacterial cultures. Five drops of Kovac's reagent were also added to each tube for confirmation of IAA production (Hussain et al., 2019).

\section{Phosphate solubilization}

Phosphate solubilization test was performed following the procedure of Gupta et al. (2012). Sterilized Pikovaskaya's media was poured into the Petri plates. Inoculated plates were placed in an incubator for 7 days at $28^{\circ} \mathrm{C}$.

\section{Ammonia production}

Peptone water (peptone $10 \mathrm{~g}$ and $\mathrm{NaCl} 5 \mathrm{~g} / \mathrm{L}, \mathrm{pH}$ $7 \pm 0.2$ ) was used to test bacterial isolates for ammonia production (Dinesh et al., 2015). Freshly grown cultures were inoculated in $10 \mathrm{ml}$ peptone water in each tube and incubated for $48-72 \mathrm{~h}$ at $36 \pm 2^{\circ} \mathrm{C}$. After that, Nessler's reagent $(0.5 \mathrm{ml})$ was mixed in each tube. Development of brown to yellow color showed positive test for ammonia production.

\section{Hydrogen cyanide (HCN) production}

Bacterial isolates were screened out for $\mathrm{HCN}$ production by streaking bacteria on plate containing LB agar supplemented with $4.4 \mathrm{~g} / \mathrm{L}$ glycine. The filter papers were cut in round shape. The dipped filter paper was placed in upper lid of plate. Para film was used to seal the plates to avoid gas discharge and incubated for 5 days at $30^{\circ} \mathrm{C}$. Change in color of filter paper from yellow to orange, brown was considered as a positive indication of HCN production (Amna et al., 2019).

\section{Siderophore production}

The proposed protocol of Louden et al. (2011) was implemented for the assay of siderophore production. A loop full of selected isolates was inoculated on selective media (without iron) amended with CASsubstrate and kept incubated at $30^{\circ} \mathrm{C}$ for 7 days. The appearance of orange colored halo zone around the colony was an indication of siderophore production.

\section{Extracellular enzyme activities of the isolates Protease Production}

Skim milk agar medium was used to evaluate the protease activity. Media was autoclaved and plates were prepared. Bacterial strains were spot inoculated on skimmed milk media plates and placed in an incubator at $30^{\circ} \mathrm{C}$ for $2-3$ days. Formation of halo zone around bacterial colony was considered as a positive indication of protease production (Ahmed et al., 2016).

\section{Pectinase Production}

All 70 isolates were screened for their pectinase producing capability by spot inoculation on agar plates. After inoculation, plates were sealed with parafilm and incubated at $30^{\circ} \mathrm{C}$ for 2 days. After completion of incubation period plates were flooded with iodine solution, and the formation of halo zone was taken as a positive indication of pectinase production (Tiru et al., 2013).

\section{Amylase production}

Bacterial Isolates were tested for amylase production following the method of Ashwini and Gaurav (2011). A loop full of the bacterial colony was spot inoculated in agar plate. Incubation of plates was done for 2 days at $28^{\circ} \mathrm{C}$. After completion of the incubation period, plates were saturated with iodine solution and formation of halo zone around bacterial colony was observed. Formation of halo zone showed positive result of amylase production

\section{Catalase production}

For testing catalase (CAT) enzyme activity, a single bacterial colony from $24 \mathrm{hrs}$ old bacterial culture was placed on a clean glass slide and a drop of $30 \%\left(\mathrm{H}_{2} \mathrm{O}_{2}\right)$ hydrogen peroxide was added upon it. Production of gas bubbles indicated that CAT enzyme is present in the bacteria (Naseem and Bano, 2014).

\section{ACC- Deaminase Acivity}

The method of Pandey and Gupta (2019) was used to screen the bacterial isolates being able to utilize ACC as a nitrogen source. These bacterial cultures were 
inoculated by spotting on petri plates containing minimal DF (Dworkin and Foster) salt media per liter supplemented with and without ACC. DF salt media with ammonium sulfate was taken as positive control The growth on ACC supplemented plates were compared to positive and negative controls after three days of incubation at $28 \pm 2{ }^{\circ} \mathrm{C}$ and isolates using ACC as a source of nitrogen were selected.

\section{Screening of bacteria for heat tolerance potential}

The isolates were screened for their heat tolerance ability against different temperature ranges $\left(32-60^{\circ} \mathrm{C}\right)$ on LB solid agar media (Ali et al., 2009).

\section{Growth curve under heat stress}

Selected isolates were cultured on LB broth under temperature ranges of $32-60^{\circ} \mathrm{C}$ to determine its growth potential. Bacterial cultures were kept on shaking at different temperatures for seven days. Spectrophotometer (Agilent 8453 UV-visible Spectroscopy System)) was used to measure the optical density (OD) of each isolate at $600 \mathrm{~nm}$ wavelength after every $24 \mathrm{~h}$ up to seven days consecutively. The bacterial isolates having optical density value $>0.2$ at $600 \mathrm{~nm}$ at maximum temperature of $60^{\circ} \mathrm{C}$ were considered as thermo-tolerant and selected for further studies (Khan et al., 2020).

\section{Morphological Characterization and colony morphology}

Fresh colony of each isolate was streaked on LB agar plates and kept in incubator at $28^{\circ} \mathrm{C}$ for $24 \mathrm{~h}$. The purified isolates were cultured on solid media for the observation of morphological characterization such as colony surface, margins, color, texture as well as shape and elevation, colony color, colony margins, colony surface texture, colony shape (Mehmood et al., 2021)

\section{Gram staining and cell morphology}

The purified isolates were further analyzed by Gram staining technique.

\section{Quantitative assay of ACC-deaminase activity}

Bacterial isolates were characterized for quantitative estimation of ACC-deaminase activity after qualitative screening. Selected isolate was grown in $5 \mathrm{ml}$ of Tryptic Soy Broth (TSB) under normal and heat stressed condition and centrifuged after $24 \mathrm{~h}$ to obtain cell pellets. The pellets were washed with $0.1 \mathrm{MTris}-\mathrm{HCl}(\mathrm{pH} 7.5)$. These cells were supplemented with DF minimal medium that was supplemented with $3 \mathrm{mM}$ ACC. Cells put into incubator shaker for $72 \mathrm{~h}$. In each sample concentration of $\alpha$-ketobutyrate was analyzed to measure ACC-deaminase activity (Khan and Khan, 2014).

\section{Characterization through QTS-24 kit}

Strains were assessed for different secondary metabolites production (Yasmin and Bano, 2011). Freshly grown strains were inoculated to QTS tubes and incubated for $24 \mathrm{~h}$ at $37^{\circ} \mathrm{C}$. After completion of incubation process, reagents were added to QTS strips according to the instructions given in manual and results were noted.

Qualitative and quantitative assay of exopolysaccharide (EPS) production

Qualitative and quantitative assessment of exopolysaccharide was done under normal and high temperature conditions by following Mukhtar et al. (2020a). The strain T6 was also checked for exopolysaccharide (EPS) production by culturing on ATCC medium no. 14 and incubated at $32^{\circ} \mathrm{C}$ for 3 to $4 \mathrm{~d}$. Slimy growth of strain was indication of EPS activity. Furthermore, EPS produced by strain PM31 was also quantified

\section{DNA extraction}

DNA of all selected bacterial strains was extracted by Phenol-chloroform. (Mukhtar et al., 2020b).

\section{Polymerase Chain Reaction for 16S rRNA genes}

Extracted DNA was amplified with 16S rRNA genes given below:

27F: 5-AGAGTTTGATC AC TGGCTCAG-3, 1492R: 5-CGG CTTACCTTGTTACGACTT-3. These aligned sequences were used for the construction of phylogenetic tree through mega 6.0 software (Mukhtar et al., 2020b).

\section{Amplification of acds gene}

Universal primers described by Duan et al. (2009) were used to amplify $a c d s$ gene responsible for ACC deaminase enzyme. Primer sequences were, Forward: 5'-GGCAAGGTCGACATCTATGC-3', Reverse: 5'GGCTTGCCATTCAGCTATG-3'.

\section{Agarose gel Electrophoresis}

The PCR products were observed in $2 \%$ agarose gel made in $1 \mathrm{X}$ TAE buffer. Samples were run at $85 \mathrm{~V}$ for $35 \mathrm{~min}$ in a horizontal electrophoresis unit and were visualized in a gel doc system (Mukhtar et al., 2020b). 


\section{Evaluation of plant growth regulators under normal and high temperature \\ Extraction and purification}

Extraction, purification, and quantification of growth regulator from bacterial cultures were made to understand the mechanism of growth promotion of these microbes used as inoculants. Growth media $(100 \mathrm{ml})$ was inoculated with $24 \mathrm{hrs}$ old bacterial cultures and incubated at $30^{\circ} \mathrm{C}$ on a shaker at 100 rpm for 7 days until OD of cultures became equivalent to 1 at $600 \mathrm{~nm}$.

\section{Quantification of growth regulators}

Quantification of growth regulators was carried out on HPLC (Agilent 1100) using a UV detector and C18 column $(39 \times 300 \mathrm{~mm})$. The IAA, GA3 and Kinetin (Commercially grade, Sigma chemical company the USA) were used as a standard for identification and quantification of IAA, GA3 and Kinetin produced by bacterial isolates. Methanol: acetic acid: water $(30: 1: 70 ; \mathrm{v} / \mathrm{v})$ was used as the mobile phase at the rate of $1500 \mu 1 / \mathrm{min}$ with a run time of $20 \mathrm{~min} / \mathrm{sample}$. Samples $(100 \mu \mathrm{l})$ were filtered through a 0.45 Millipore filter and injected into the column. The growth regulators were identified based on the retention time of the standard IAA using a UV detector at 280nm wavelength and GA3 and Kinetin at $254 \mathrm{~nm}$ respectively (Kapoor et al., 2016)

\section{Field experiment}

\section{Inoculum preparation}

Luria Bertani media was used to make fresh bacterial cultures. Centrifugation of broth was done at 3000 rpm for $10 \mathrm{~min}$. Pellet was collected and dispersed in autoclaved double distilled water $\left(\mathrm{dH}_{2} \mathrm{O}\right)$, and optical density was set to $10^{9}$ colony forming unit (CFU) at $660 \mathrm{~nm}$. Tomato seeds (Riogrande Variety) was soaked in bacterial strain T6 for 2-4 hours before sowing in pots (Amna et al., 2019).

\section{Experimental design for field condition}

A total of three field experiments were conducted at National Agriculture Research Centre (NARC), Islamabad (during 2018 and 2019) and district Muzaffargarh (during 2019) systematically. Studied strain was analyzed in two consecutive years along with two different locations. Field experiments comprised of four treatments i.e. C, control (uninoculated, $30{ }^{\circ} \mathrm{C}$ ); $\mathrm{T} 1$, plants with bacterial inoculation; T2, plants under heat stress without inoculation of bacteria; $\mathrm{T} 3$, plants under heat stress with inoculation of bacteria. Temperature of control was $30{ }^{\circ} \mathrm{C}$. Heat stress was maintained using a transparent plastic sheet. Remaining all practices including irrigation was done according to production technology of tomato (Chand et al., 2021). Experiment was conducted with three replicates. Field experiment was conducted with completely randomized block design. The tomato plants were harvested after 96 days of sowing.

Agronomical, photosynthetic, and biochemical analyses of plants

Shoot and root length

Length of freshly harvested shoots and roots was measured using measuring tape (Hussain et al., 2019).

\section{Fresh and dry weight of tomato plant}

Fresh weight of harvested plants was measured using digital balance. Dry weight was measured after drying the plants in oven at $70^{\circ} \mathrm{C}$ for 2 days in paper bags. Weight of fully dried plants was measured using digital balance (Hussain et al., 2019).

\section{Number of flowers and fruits}

Number of flowers and fruits were counted in every treatment with naked eye (Mukhtar et al., 2020a).

\section{Chlorophyll $a, b$ and carotenoid contents}

Chlorophyll contents were estimated using $0.1 \mathrm{~g}$ leaf material from each treatment. Small pieces of fresh leaves were incubated in $4 \mathrm{~mL} \mathrm{DMSO}_{4}$ (Dimethylsulfoxide) (Muneer et al., 2020a; Muneer et al., 2020b). Absorbance was recorded using spectrophotometer (752 N UV-VIS, Beijing, China). Chlorophyll $a$, chlorophyll $b$ and carotenoid contents were calculated by following formulas.

$\mathrm{Chl} \mathrm{a}(\mathrm{mg} / \mathrm{g})=[1.07(\mathrm{OD} 663)-0.09(\mathrm{OD} 645)]$

$\mathrm{Chl} \mathrm{b}(\mathrm{mg} / \mathrm{g})=[1.77(\mathrm{OD} 645)-0.280(\mathrm{OD} 663)]$

Carotenoid $(\mathrm{mg} / \mathrm{g})=($ O.D.480 nm $)-0.144($ O.D.663 $\mathrm{nm})-0.6308$ (O.D.645 nm)

\section{Statistical analysis}

Analysis of variance was performed using Statistixs software (Version 8.1) for both varieties based on bacterial (control or inoculated) and temperature treatments (non-heat and under heat stress). Completely randomized block design was used for current field experiment. Adjustments for multiple comparisons were made using the LSD test, keeping significant level at $p \geq 0.05$. The application of bi-plots correlation analysis was performed on mean values of 
all variables using XL-STAT 2015. Shapiro wilk test (Wang and Riffel, 2011) was conducted for checking the normality level field data in current experiment.

\section{Results}

\section{Sample collection and isolation}

Seventy isolates were obtained from samples. These seventy isolates were purified, preserved and characterized. Most promising isolate was obtained that survived against high temperature and played role in plant growth promotion and extracellular enzyme production.

Table-1: Morphological and biochemical characterization of Bacillus Safensis strain T6

\begin{tabular}{|c|c|c|}
\hline Traits & Properties & \\
\hline \multirow[t]{8}{*}{ Morphological } & Temperature range & $30-60^{\circ} \mathrm{C}$ \\
\hline & Colony color & off white \\
\hline & Shape & rod \\
\hline & Elevation & convex \\
\hline & Form & circular \\
\hline & Opacity & transparent \\
\hline & Margin & lobate \\
\hline & Gram staining & $\begin{array}{c}\text { Gram } \\
\text { Positive }\end{array}$ \\
\hline \multirow[t]{28}{*}{ Biochemical } & ACC deaminase & + \\
\hline & Phosphorous solubilization & + \\
\hline & IAA & + \\
\hline & EPS production & + \\
\hline & $\mathrm{HCN}$ & + \\
\hline & Ammonia & + \\
\hline & Catalase & + \\
\hline & Amylase & + \\
\hline & Pectinase and protease & + \\
\hline & Tryptophan deaminase & + \\
\hline & Urea & + \\
\hline & Indole & + \\
\hline & Glucose & + \\
\hline & Sodium citrate & + \\
\hline & Melibiose & + \\
\hline & Ornithine decarboxylase & + \\
\hline & $\mathrm{H}_{2} \mathrm{~S}$ & + \\
\hline & Maltose & + \\
\hline & Sucrose & + \\
\hline & Sorbitol & + \\
\hline & Inositol & + \\
\hline & Raffinose & + \\
\hline & Sodium malonate & - \\
\hline & Lysine decarboxylase & - \\
\hline & Gelatin hydrolysis & - \\
\hline & $\begin{array}{l}\text { Ortho nitro phenyl } \beta \text {-D- } \\
\text { galactopyranoside }\end{array}$ & - \\
\hline & Arginine dihydrolase & - \\
\hline & Mannitol & - \\
\hline
\end{tabular}

\section{Indole acetic acid (IAA) production}

Cherry red rings were formed by studied strain (T6) due to IAA production on the top of the test tube (Table.1).

Phosphate solubilization, ammonia and HCN production

Studied strain showed positive result for Psolubilization (Table 1). Ammonia production was confirmed upon formation of brown to yellow color in all 70 strains (Table.1) Bacterial isolate (T6) out of seventy, showed the positive result for $\mathrm{HCN}$ production. (Table. 1).

\section{Extracellular enzyme tests}

The strain T6 showed a positive response towards extracellular enzymes protease, pectinase, amylase and catalase producing ability (Table. 1 ).

Morphological observation through compound microscope and naked eye, plant growth promoting activities and biochemical characterization of bacterial strain through QTS-24 kits.

\section{Screening of isolates against heat stress}

Only 1 bacterial isolate out of 70 survived till $60^{\circ} \mathrm{C}$ (Table. 2, Figure.1).

Table-2: Number of heat tolerant bacterial isolates

\begin{tabular}{|c|c|c|}
\hline Serial & Temperature range & Number of isolates \\
\hline $\mathbf{1 .}$ & $60^{\circ} \mathrm{C}$ & 1 \\
\hline $\mathbf{2 .}$ & 55 to $59^{\circ} \mathrm{C}$ & 17 \\
\hline $\mathbf{3}$. & 51 to $55^{\circ} \mathrm{C}$ & 23 \\
\hline $\mathbf{4 .}$ & 41 to $50^{\circ} \mathrm{C}$ & 62 \\
\hline $\mathbf{5}$. & 32 to $40^{\circ} \mathrm{C}$ & 70 \\
\hline
\end{tabular}

Number of isolates against different temperature

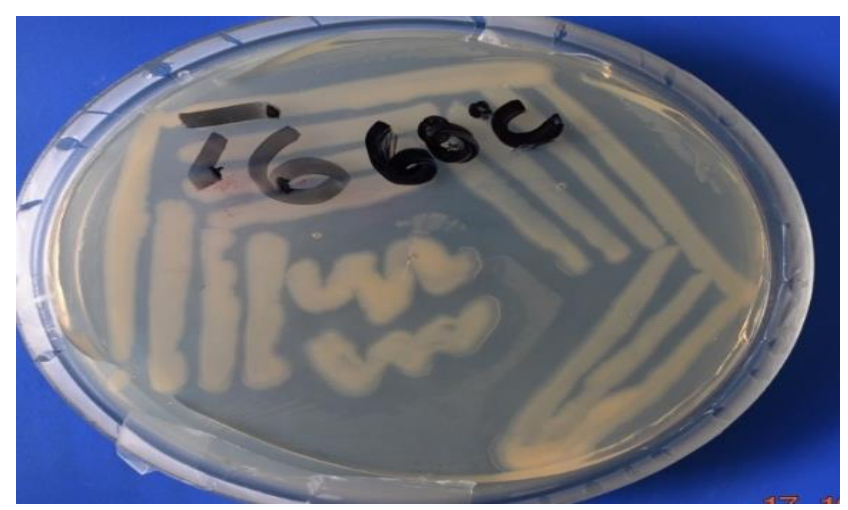

Figure-1: Growth of bacterial isolates on LB solid media against different temperature 
Growth curve analysis of selected bacterial isolates

Growth curve analysis of selected bacterial isolates against different temperature ranges for 7 days is shown in Figure 2. The growth curve analysis of bacterial isolate $\mathrm{T} 6$ revealed peak growth at $2^{\text {nd }}$ day and started decline at optimum temperature of selected bacterial isolate. Peak growth at 2 nd and $3^{\text {rd }}$ day was noted at $50^{\circ} \mathrm{C}$ and $60^{\circ} \mathrm{C}$, respectively, as shown in Figure 2.

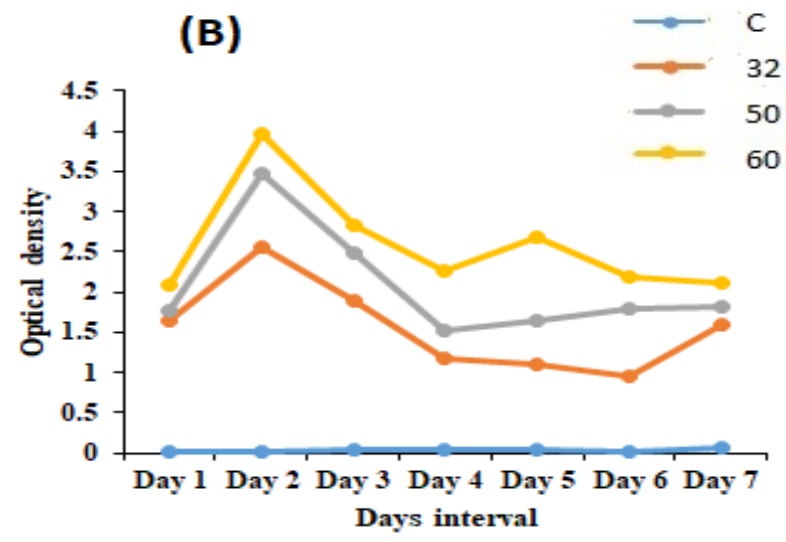

Figure-2: Growth curve analysis of bacterial isolate T6, under different temperature level against control Morphological characterization

Bacterial isolates showed their characteristics through cell morphology, color, shape and Gram staining reaction (Table 1).

Quantitative assay of ACC-deaminase and exopolysaccharide (EPS) production

Bacterial Isolate T6 produced maximum quantity of enzyme activity $(0.95 \mu \mathrm{M} / \mathrm{mg}$ protein $/ \mathrm{h})$ under the stress condition. EPS production in isolate T6 was 0.9 and $0.71 \mathrm{mg} / \mathrm{ml}$ under heat stress and non-heat stress conditions as shown in table. 3

Table-3: Quantitative assessment of ACCdeaminase and exopolysaccharides (EPS) in culture of $B$. safensis $\mathrm{T} 6$ with and without heat stress

\begin{tabular}{|c|c|c|c|c|}
\hline \multirow{2}{*}{ Strain } & \multicolumn{2}{|c|}{$\begin{array}{c}\text { Acc-deaminase } \\
\text { Activity } \\
(\mu \mathrm{M} / \mathrm{mg} \text { protein } / \mathrm{h})\end{array}$} & \multicolumn{2}{|c|}{$\begin{array}{c}\text { EPS production } \\
(\mathrm{mg} / \mathrm{mL})\end{array}$} \\
\hline & $\begin{array}{l}\text { Non- } \\
\text { heat }\end{array}$ & $\begin{array}{c}\text { Heat } \\
\text { condition }\end{array}$ & $\begin{array}{c}\text { Non- } \\
\text { heat }\end{array}$ & condition \\
\hline $\begin{array}{c}B . \\
\text { safensis }\end{array}$ & $\begin{array}{c}0.83 \pm \\
0.012 \\
\end{array}$ & $\begin{array}{c}0.95 \pm \\
0.011\end{array}$ & $\begin{array}{c}0.71 \pm \\
0.02\end{array}$ & $0.9 \pm 0.01$ \\
\hline
\end{tabular}

Acds gene amplification

The PCR mediated amplification of acds gene of studied strain was performed using a universal set of primers (Figure 3). Although, ACC deaminase enzyme activity was confirmed quantitatively in all strains but by using the set of primers its activity was further verified by the amplification of gene in the selected strains. The amplified product was captured using agarose gel electrophoresis.

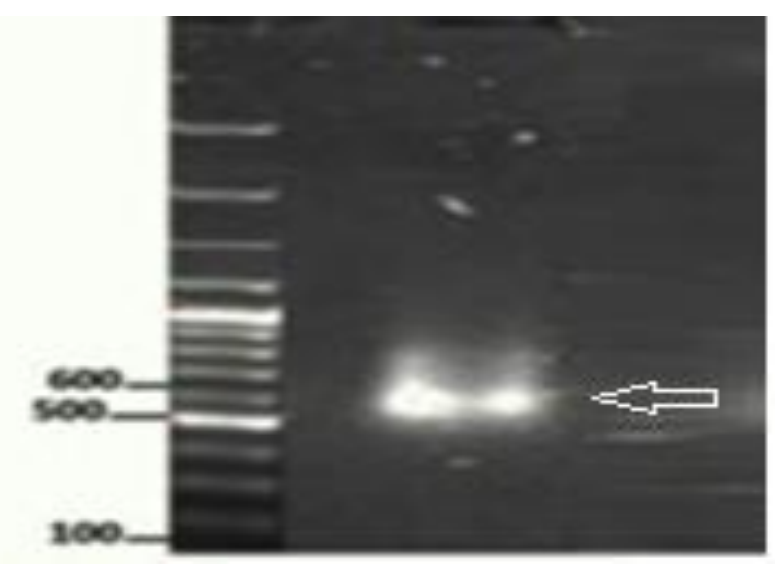

Figure-3: Gel imaging picture of amplification and presence of $a c d c$ gene in the selected bacterial Isolate (T6,)

Characterization of selected bacterial strain through QTS-24 kit

The selected strain that exhibited positive results for different tests was characterized through microbial identification kit QTS-24 (Table1). Whereas T6 showed positive for all tests done with microbial identification kit.

\section{Identification of selected bacterial strain}

Molecular identification of studied isolate (T6) was carried through 16S rRNA gene sequencing. Studied isolate was identified as Bacillus safensis (Table.4)

Table-4: Identification of the bacterial isolate by 16S rRNA gene technique.

\begin{tabular}{|c|c|c|c|}
\hline Sr. No. & $\begin{array}{c}\text { Isolates } \\
\text { Code }\end{array}$ & Scientific name & $\begin{array}{c}\text { Accession } \\
\text { number }\end{array}$ \\
\hline $\mathbf{1 .}$ & $\mathrm{T} 6$ & Bacillus safensis & MK910213 \\
\hline
\end{tabular}

\section{Agronomic parameters}

\section{Analysis of growth parameters}

Plant biomass parameters and number of flowers, fruits and leaf surface area were significantly increased with inoculation of $B$. safensis under heat stress (T3) in two field trials at National Agriculture Research Centre Islamabad, Pakistan during 2018- 
2019 and in Muzaffargarh, Punjab, Pakistan during 2019. Heat stress reduced plants shoot and root length in Riogrande (tomato variety) and reduced growth, in general, was observed in direct relationship with the increasing level of temperature. Heat stress along with bacterium inoculation demonstrated maximum shoot and root length in Riogrande. Heat stress without bacterium inoculation revealed minimum fresh and dry weight in Riogrande. Heat stress with bacterium inoculation revealed maximum fresh and dry weight in Riogrande. Heat stress without bacterium inoculation showed minimum number of flowers and fruits in Riogrande. Bacterium inoculation revealed maximum number of flowers and fruits in Riogrande under heat stress (Table.5, 6 and 7).

\section{Effects of $B$. safensis on photosynthetic pigments} Photosynthetic pigments such as Chlorophyll $a, b$ and carotenoids of Riogrande (tomato variety) was observed in increased concentration in bacterium inoculated treatment under normal conditions (T1) as compared with control treatment (C). Similarly, photosynthetic pigments increased in heat stress with bacterium inoculation treatment (T3) in comparison to heat stress without bacterium inoculation treatment (T2) (Table 5, 6 and 7).

Table-5: Results of field study conducted in National Agriculture Research center (year 2018)

\begin{tabular}{|c|c|c|c|c|c|c|c|c|c|}
\hline Treatments & $\begin{array}{c}\text { Shoot } \\
\text { length }(\mathbf{c m})\end{array}$ & $\begin{array}{c}\text { Root } \\
\text { length } \\
(\mathbf{c m})\end{array}$ & $\begin{array}{c}\text { Fresh } \\
\text { weight } \\
(\mathbf{k g})\end{array}$ & $\begin{array}{c}\text { Dry } \\
\text { weight } \\
(\mathbf{k g})\end{array}$ & $\begin{array}{c}\text { No of } \\
\text { flowers }\end{array}$ & $\begin{array}{c}\text { No of } \\
\text { fruits }(\mathbf{n})\end{array}$ & $\begin{array}{c}\text { Chlorophyll } \\
\boldsymbol{a}(\mathbf{m g} / \mathbf{g})\end{array}$ & $\begin{array}{c}\text { Chlorophyl } \\
\mathbf{l} \boldsymbol{b}(\mathbf{m g} / \mathbf{g})\end{array}$ & $\begin{array}{c}\text { Carotenoid } \\
\mathbf{c o n t e n t} \\
(\mathbf{m g} / \mathbf{g})\end{array}$ \\
\hline Control & $96.6 \pm 1.4 \mathrm{c}$ & $43 \pm 2.6 \mathrm{dc}$ & $0.50 \pm 0.01 \mathrm{~d}$ & $20.1 \pm 0.3 \mathrm{~b}$ & $58 \pm 0.5 \mathrm{c}$ & $37 \pm 1.15 \mathrm{c}$ & $1.8 \pm 0.01 \mathrm{c}$ & $1.6 \pm 0.02 \mathrm{c}$ & $9.6 \pm 0.03 \mathrm{~b}$ \\
\hline $\mathrm{T} 1$ & $197.3 \pm 2.3 \mathrm{a}$ & $64 \pm 2.0 \mathrm{a}$ & $1.74 \pm 0.01 \mathrm{a}$ & $26.1 \pm 0.7 \mathrm{a}$ & $82 \pm 101 \mathrm{a}$ & $54.6 \pm 1.2 \mathrm{a}$ & $4.2 \pm 0.01 \mathrm{a}$ & $3.5 \pm 0.05 \mathrm{a}$ & $22.6 \pm 1.7 \mathrm{a}$ \\
\hline $\mathrm{T} 2$ & $71.3 \pm 2.0 \mathrm{~d}$ & $24 \pm 1.7 \mathrm{~d}$ & $0.96 \pm 0.08 \mathrm{c}$ & $11.5 \pm 0.5 \mathrm{c}$ & $45 \pm 1.1 \mathrm{~d}$ & $35.3 \pm 1.4 \mathrm{~cd}$ & $0.9 \pm 0.02 \mathrm{~d}$ & $0.7 \pm 0.03 \mathrm{~d}$ & $5.3 \pm 0.01 \mathrm{c}$ \\
\hline $\mathrm{T} 3$ & $177.6 \pm 1.8 \mathrm{~b}$ & $57 \pm 2.2 \mathrm{~b}$ & $1.13 \pm 0.03 \mathrm{~b}$ & $20.5 \pm 0.4 \mathrm{~b}$ & $76 \pm 1.0 \mathrm{~b}$ & $47 \pm 1.15 \mathrm{~b}$ & $3.1 \pm 0.01 \mathrm{~b}$ & $3 \pm 0.005 \mathrm{~b}$ & $15.6 \pm 0.3 \mathrm{~d}$ \\
\hline
\end{tabular}

Control represents un-inoculated; T1: Bacillus safensis; T2: heat stress; T3: B. safensis +heat stress

Table-6: Results of field study conducted in National Agriculture Research center (year 2019)

\begin{tabular}{|c|c|c|c|c|c|c|c|c|c|}
\hline $\begin{array}{c}\text { Treatment } \\
\mathbf{s}\end{array}$ & $\begin{array}{c}\text { Shoot } \\
\text { length } \\
(\mathbf{c m})\end{array}$ & $\begin{array}{c}\text { Root } \\
\text { length } \\
(\mathbf{c m})\end{array}$ & $\begin{array}{c}\text { Fresh } \\
\text { weight } \\
(\mathbf{k g})\end{array}$ & $\begin{array}{c}\text { Dry weight } \\
(\mathbf{k g})\end{array}$ & $\begin{array}{c}\text { No of } \\
\text { flowers }(\mathbf{n})\end{array}$ & $\begin{array}{c}\text { No of } \\
\text { fruits }(\mathbf{n})\end{array}$ & $\begin{array}{l}\text { Chlorophy } \\
\mathbf{l l} \boldsymbol{a}(\mathbf{m g} / \mathbf{g})\end{array}$ & $\begin{array}{c}\text { Chlorophy } \\
\mathbf{l l} \boldsymbol{b}(\mathbf{m g} / \mathbf{g})\end{array}$ & $\begin{array}{c}\text { Carotenoid } \\
(\mathbf{m g} / \mathbf{g})\end{array}$ \\
\hline Control & $102.6 \pm 2.1 \mathrm{c}$ & $42.6 \pm 2.0 \mathrm{dc}$ & $0.61 \pm 0.02 \mathrm{~d}$ & $21.4 \pm 0.28 \mathrm{~b}$ & $53.6 \pm 0.88 \mathrm{c}$ & $38.3 \pm 0.6 \mathrm{~d}$ & $1.88 \pm 0.04 \mathrm{c}$ & $1.72 \pm 0.01 \mathrm{c}$ & $10 \pm 0.13 \mathrm{c}$ \\
\hline $\mathrm{T} 1$ & $200.3 \pm 2.0 \mathrm{a}$ & $62 \pm 2.3 \mathrm{a}$ & $1.69 \pm 0.03 \mathrm{a}$ & $24.8 \pm 0.27 \mathrm{a}$ & $84.2 \pm 2.08 \mathrm{a}$ & $56.3 \pm 1.76 \mathrm{a}$ & $4.31 \pm 0.00 \mathrm{a}$ & $3.72 \pm 0.0 \mathrm{a}$ & $23.3 \pm 0.14 \mathrm{a}$ \\
\hline $\mathrm{T} 2$ & $73.3 \pm 2.3 \mathrm{~d}$ & $23.6 \pm 2.7 \mathrm{~d}$ & $1.1 \pm 0.05 \mathrm{~b}$ & $11.4 \pm 0.25 \mathrm{~d}$ & $43.6 \pm 1.45 \mathrm{~d}$ & $40.3 \pm 1.85 \mathrm{c}$ & $0.74 \pm 0.02 \mathrm{~d}$ & $0.83 \pm 0.01 \mathrm{~d}$ & $3.88 \pm 0.02 \mathrm{~d}$ \\
\hline T3 & $186.3 \pm 2.2 \mathrm{~b}$ & $55.9 \pm 4.1 \mathrm{~b}$ & $0.85 \pm 0.05 \mathrm{c}$ & $20 \pm 0.05 \mathrm{bc}$ & $76.6 \pm 1.20 \mathrm{~b}$ & $45.3 \pm 2.02 \mathrm{~b}$ & $3.1 \pm 0.02 \mathrm{~b}$ & $3.19 \pm 0.01 \mathrm{~b}$ & $17.6 \pm 0.37 \mathrm{~b}$ \\
\hline
\end{tabular}

Table-7: Results of field study conducted in Muzaffargarh (year 2019)

\begin{tabular}{|c|c|c|c|c|c|c|c|c|c|}
\hline $\begin{array}{c}\text { Treatment } \\
\text { s }\end{array}$ & $\begin{array}{c}\text { Shoot } \\
\text { length }(\mathrm{cm})\end{array}$ & $\begin{array}{c}\text { Root } \\
\text { length } \\
(\mathrm{cm})\end{array}$ & $\begin{array}{c}\text { Fresh } \\
\text { weight } \\
(\mathbf{k g})\end{array}$ & $\begin{array}{c}\text { Dry } \\
\text { weight } \\
\text { (kg) }\end{array}$ & $\begin{array}{c}\text { No of } \\
\text { flowers }\end{array}$ & $\begin{array}{l}\text { No of } \\
\text { fruits }\end{array}$ & $\begin{array}{r}\text { Chlo } \\
a(\end{array}$ & $\begin{array}{r}\text { Chlo } \\
b(\end{array}$ & (m \\
\hline & & $43 \pm 2.6 c$ & $50 \pm 0.01 \mathrm{~d}$ & $20.1 \pm 0.3 b$ & & & & & \\
\hline $\mathrm{T} 1$ & $197.3 \pm 2.3 \mathrm{a}$ & $64 \pm 2.1 \mathrm{a}$ & $1.74 \pm 0.01 \mathrm{a}$ & $26.1 \pm 0.7 \mathrm{a}$ & $82 \pm 1.1 \mathrm{a}$ & $54.6 \pm 1.2 \mathrm{a}$ & $4.2 \pm 0.01 \mathrm{a}$ & $3.5 \pm 0.05 a$ & $22.6 \pm 1.73 a$ \\
\hline $\mathrm{T} 2$ & d & $24 \pm$ & c & $\mathrm{c}$ & $45 \pm 1.1 d$ & $35.3 \pm 1.4 \mathrm{~d}$ & & & $5.3 \pm$ \\
\hline $\mathrm{T} 3$ & $77.6 \pm 1.8 \mathrm{~b}$ & $57 \pm 2.2 b$ & $1.13 \pm 0.03 b$ & $20.5 \pm 0.4 b$ & $76 \pm 1.1 b$ & $47 \pm 1.15 b$ & $3.1 \pm 0.01 \mathrm{~b}$ & $3 \pm 0.005 b$ & $15.6 \pm 0.36 b$ \\
\hline
\end{tabular}

Control represents un-inoculated; T1: Bacillus safensis; T2: heat stress; T3: B. safensis +heat stress 
Pearson correlation analysis of $B$. safensis (T6) in field condition during 2018 and 2019

Treatment graph showed that less variation among the blue dots means that treatments are significantly correlated with each other (Figure. 4. A-c). Pearson correlation bi-plot analysis revealed $97.16 \%$ of the total variation between the plotted data F1 and F2. F1 and F2 individually contributed about $88.2 \%$ and $8.96 \%$ variation, respectively during 2018 .

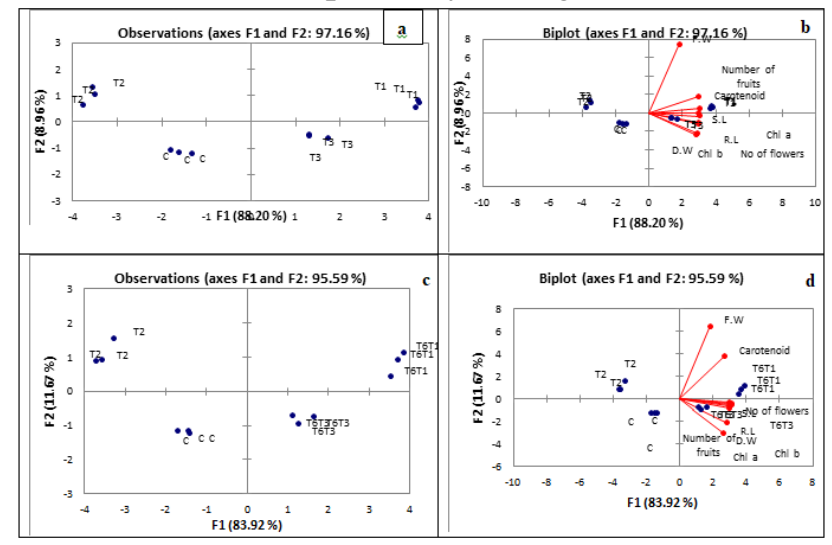

Figure-4: Pearson correlation of interaction of bacteria with plants in field condition. a-c (treatment test) and b-d (Biplot analysis).

\section{Normality test}

\begin{tabular}{|c|c|c|c|}
\hline \multirow{2}{*}{ Field 2018} & \multicolumn{3}{|c|}{ Shapiro-Wilk } \\
\hline & Statistic & df & Sig. \\
\hline Shoot length & 0.901 & 4 & 0.437 \\
\hline Root Length & 0.9 & 4 & 0.429 \\
\hline Fresh weight & 0.955 & 4 & 0.746 \\
\hline Dry weight & 0.987 & 4 & 0.94 \\
\hline Noor flower & 0.981 & 4 & 0.91 \\
\hline Noof fruit & 0.977 & 4 & 0.883 \\
\hline Chl A & 0.944 & 4 & 0.681 \\
\hline Chlo B & 0.986 & 4 & 0.938 \\
\hline Carotenoid & 0.98 & 4 & 0.902 \\
\hline \multirow{2}{*}{ Field 2019} & \multicolumn{3}{|c|}{ Shapiro-Wilk } \\
\hline & \multicolumn{2}{|l|}{ Statistic } & Sig. \\
\hline Shoot length & \multicolumn{2}{|l|}{.954} & .738 \\
\hline Root Length & \multicolumn{2}{|l|}{.972} & .853 \\
\hline Fresh weight & \multicolumn{2}{|l|}{.924} & .558 \\
\hline Dry weight & \multicolumn{2}{|l|}{.940} & .657 \\
\hline No of flower & \multicolumn{2}{|l|}{.981} & .910 \\
\hline No of fruit & \multicolumn{2}{|l|}{.977} & .883 \\
\hline Chlorophyll contents & \multicolumn{2}{|l|}{.961} & .786 \\
\hline
\end{tabular}

Pearson correlation bi-plot analysis revealed $95.5 \%$ of the total variation between the plotted data $\mathrm{F} 1$ and F2. F1 and F2 individually contributed about $83.9 \%$ and $11.6 \%$ variation, respectively during 2019. All growth parameters of tomato plants were positively correlated with inoculation of strain T6 under heat stress conditions. Bacterial strain B. safensis (T6) exhibited a strong positive response towards various plant growth parameters under heat stress condition as revealed from principal component analysis All studied parameters revealed the significant positive correlation among growth parameters (Figure.4. b-d).

\section{Discussion}

Different environmental stresses, particularly heat stress, have a substantial impact on agricultural production, which is becoming increasingly worrying with the passage of time. To overcome heat stress, sophisticated environmentally friendly and costeffective solutions must be used (Batool et al., 2019; Mukhtar et al., 2020a; Mehmood et al., 2021). The Plant growth promoting bacteria (PGPB) is well reported to improve plant growth as well as and discussed tolerant to different abiotic stresses (Amna et al., 2019; Ali et al., 2021). The inoculation of PGPB resulted in increased agronomic variables such as roots, shoot length, leaf surface area, number of flowers and fruits, fresh and dry weight, and chlorophyll a, b, and carotenoid content in the current experiment. PGPB is a microbial flora found asymptomatically in all plant sections that improves nutrient uptake and protects host plants from the negative effects of heat stress (Ali et al., 2018; Mukhtar et al., 2020b; Zainab et al., 2020).

In the recent investigation, enhanced shoot, and root length under normal (T1) and heat stress (T3) compared to control (C) and un-inoculated heat treatment (T2) were observed. Also, Riogrande revealed higher shoot and root length. Our findings are supported by Mehmood et al. (2021) as they obtained enhanced shoot and root length and chlorophyll content with application of bacterial strain Bacillus subtills (MPB 2.1). IAA production aids plant growth as well as the ability to cope with various environmental conditions. Furthermore, under salinity and heat stress, Klebsiella sp. (SBP-8) considerably increased plant development. Furthermore, the current findings are consistent with Liu et al. (2013) and Din et al. (2020) who found that cytokinin-producing Bacillus spp. are resistant to 
abiotic stress.

In the present findings, plant biomass (fresh and dry weight) was enhanced under normal (T1) and heat stress (T3) PGPB inoculation as compared with uninoculated heat stress (T2) and control (C) treatments. Present results are strongly supported findings of Khan and Khan (2014) as they revealed that Bacterial inoculation enhanced plant growth attributes of wild-type and Got-3 tomato cultivars. Similar trends were documented in the study of Ali et al. (2011). Inoculation of plant growth promoting bacteria reported to decrease the toxic heat stress effects. Similar trend was observed that revealed increased plant growth with inoculation of PGPB under heat stress conditions.

Increased plant biomass of Riogrand variety was observed under heat stress. Similarly, Ali et al. (2009) reported increased plant growth and biomass production under heat stress. Furthermore, shoot, root lengths, fresh and dry weight significantly increased with Pseudomonas sp inoculation under heat stress (Chandra et al., 2018).

With PGPB inoculation, increased plant growth and biomass production may be owing to improved plant growth regulators that improve nutrient and water absorption capacity (Ali et al., 2011). In Riogrande, heat stress treatments exhibited increased chlorophyll b levels as compared to control treatments. One reason of increased chlorophyll content may be due to the enhanced photosynthetic activity in PGPB inoculated plants under normal conditions that was decreased in un-inoculated plants in stress conditions. Fahad and Bano (2012), reported that heat stress significantly declined plant photosynthesis which might be possibly due to alteration in photosynthetic mechanisms balance. Present results are in line with Ali et al. (2018) that showed enhanced chlorophyll content in shoots with inoculation $P$. putida. Increased plant growth and chlorophyll contents were observed in plants inoculated with Brevibacterium sp. (FAB3) (Asari et al., 2017, Ahmadi et al., 2015).

A total of three field experiments were conducted at National Agriculture Research Centre, Islamabad, Pakistan (during 2018 and 2019) and district Muzaffargarh, Punjab, Pakistan (during 2019). Inoculation of bacterial strains in current field experiment enhanced all agronomic parameters and chlorophyll contents under normal and heat stress condition as compared to respective control and uninoculated treatments. Fruit number per plant was enhanced significantly with inoculation of plant growth promoting bacteria (PGPB) under heat stress condition but heat stress caused poor fruit setting and led to less number of fruits in un-inoculated treatments. Temperature in the optimum scale is crucial for tomato fruit set. Fruit failure occurred in plants exposed to temperature above $104{ }^{\circ} \mathrm{F}$ for two days over 2-hour duration.

During fruit set the pollen development stage is very sensitive, that starts approximately nine days before flowering stage. During these days any variation in temperature results in poor fruit development and fruit set. PGPB increases the vegetative and reproductive growth of plants by providing phosphorus, indole acetic acid and protect plant from heat stress condition through ACC deaminase enzymes and it has direct link with tomato yield in the form of enhanced flower and fruit yield (Aini et al., 2019; Maqbool et al., 2021). Studied bacterial strain was also able to produce IAA, gibberellin, and kinetin in significant amount. Under heat stress conditions plants hormones play a vital role in plant growth as well as development, thus start fruit and flower development and finally fruit set (de Jong et al., 2009).

Bacillus safensis (T6) showed the maximum number of flowers under heat stress $(40.7 \%)$ condition as compared to respective control (T2- un-inoculated under heat stress). The Bacillus safensis (T6) produced the maximum number of fruits under heat condition at the increase of $(8.33 \%)$ when comparing with Aini et al. (2019), we also found better trend. Previous study (Wahid et al., 2007) showed that number of flowers decreased upon exposure to heat stress. In comparison to non-inoculated tomato plants, bacterial inoculation enhanced the number of flowers and fruits under heat stress and normal conditions. In addition, increasing temperature and low carbohydrate concentrations, as well as growth regulators, resulted in poor fruit setting. (Mukhtar et al., 2020a). The Bacillus safensis (T6) showed the maximum number of flower $(36.1 \%)$ under normal and heat stress $(44.1 \%)$ condition as compared to respective control (C and T2). Bacillus safensis (T6) produced the maximum number of fruits among all bacterial strains under normal $(32.3 \%)$ and under heat stress $(20.9 \%)$ condition similar to the findings of Aini et al. (2019).

Enhanced root and shoot length of plant was showed with the inoculation of plant growth promoting bacteria under normal and heat stress condition in comparison with control and un-inoculated plants 
under heat stress. Plant biomass of tomato was increased with inoculation of heat tolerant PGPB under normal and heat stress condition as compared to respective control. Results of our experiments were strengthened with the findings of Mukhtar et al. (2020a). Current results explained that photosynthetic pigments (chlorophyll a, chlorophyll b and carotenoid) were significantly increased with inoculation of Bacillus safensis (T6) under heat stress as well as normal conditions in comparison to respective control. Bacterial inoculation increased leaf surface area along with level of photosynthetic pigments and our results are supported with the findings of Afridi et al. (2019).

Heat stress significantly alters the physiological and biochemical processes of tomato plants. Reduction in tomato growth under heat stress has also been documented (Kamara et al., 2003). Inoculation of heat tolerant ACC- deaminase producing PGPB; Bacillus safensis (T6) to tomato variety (Riogrande) significantly reduced the adverse effects of heat stress. Particularly, PGPB application was more effective to plants in stress and normal condition in terms of chlorophyll, carotenoids contents, shoots, root length, fresh and dry weight. Previous study (Zahir et al., 2008) also documented an increased root length in PGPB inoculated plants that led to efficient nutrient uptake from soil. In another study, tomato plants inoculated with Klebsiella oxytoca (10MKR7), Enterobacter sakazakii (8MR5) and Pseudomonas sp. (4MKS8) exhibited improvement in various agronomic variables including root elongation. Chlorophyll content is an indicator of stability under stress conditions. Decline in chlorophyll content $(\mathrm{a}, \mathrm{b})$ under high temperature has been studied by Efeoğlu et al. (2009). Reduction in chlorophyll content is indication of photo-oxidation as previously reported (Beinsan et al., 2003)

Bacterial inoculation considerably improved chlorophyll content $(a, b)$ in tomato plants under heat stress. Carotenoids are non-enzymatic scavengers of reactive oxygen species present in substantial amount in plants (Jung et al., 2000). High carotenoids content attributed to heat stress tolerance, as they are responsible for breakdown of singlet oxygen. Since carotenoids are found in association with reaction centers (Efeoğlu et al., 2009) and loss of photosynthetic reaction center was observed in acute abiotic stress, the decline in carotenoids content was expected. Tomato plant inoculated with $B$. safensis (T6) exhibited positive response in terms of greater carotenoids contents under different water regimes. The plant growth promoting bacteria have several influences on plant hormones, improving hormonal level in shoot, enhance growth of plant and its physiological processes under stress condition (Dodd et al., 2010). The occurrence of ACC- deaminase activity helped in the chlorophyll content recovery in consortia treated plants and overcome the fatal effects of heat stress through low ethylene production (Nadeem and Imran, 2017). In stress conditions, high level of chlorophyll contents was due to enhanced leaf surface area in bacterial treated plants as compared to un-inoculated plants.

\section{Conclusion}

Seventy bacterial strains were characterized and tested for heat stress tolerance and plant growth promotion. One strain out of seventy had significant heat stress tolerance and was chosen. These bacteria were tested for ACC-deaminase, exopolysaccharide synthesis, and growth regulator quantification. The strain was tested for efficiency in the field after evidence was revealed in greenhouse study. Maximum number of flower $(40.7 \%)$ and fruits $(31.1 \%)$; flowers and fruits (44.1 and $20.9 \%)$ flowers $(16.9 \%)$ and fruits $(52.1 \%)$ were obtained with inoculation of plant growth promoting bacteria Bacillus safensis (T6) under heat stress in the year of 2018, 2019 and Muzfargarh as compared with heat stress un-inoculated. According to recent findings, inoculated bacterial strains significantly improved flower formation and fruit setting (both important yield parameters for farmers), as evidenced by increased percentages in all field studies. When compared the results were significant enough to be reported to the best of our knowledge. To the best of our knowledge in Pakistan this is the first study in which heat stress tolerant bacterial strains was used for mitigation of heat stress under field condition.

\section{Acknowledgment}

Author acknowledge the Agricultural Linkage Program (ALP) of Pakistan Agricultural Research Council for providing funding for this project.

Disclaimer: None.

Conflict of Interest: None.

Source of Funding: The research was funded by 
Agricultural Linkage Program (ALP Project \# CS374), PARC, Islamabad, Pakistan.

\section{References}

Afridi MS, Sumaira A, Mahmood T, Salam A, Mukhtar T and Chaudhary HJ, 2019. Induction of tolerance to salinity in wheat genotypes by plant growth promoting endophytes: Involvement of ACC deaminase and antioxidant enzymes. Plant Physiol. Biochem. 139: 569-577 doi:10.1016/j.plaphy.2019.03.041

Ahmad I, Akhtar MJ, Mehmood S, Akhter K, Tahir M, Saeed MF and Hussain S, 2018. Combined application of compost and Bacillus sp. CIK-512 ameliorated the lead toxicity in radish by regulating the homeostasis of antioxidants and lead. Ecotoxicol. Environ. Saf. 148: 805-812.

Ahmed M, Rehman R, Siddique A, Hasan F, Ali N and Hameed A, 2016. Production, purification and characterization of detergent-stable, halotolerant alkaline protease for eco-friendly application in detergents' industry. Int. J. Biosci, 8(2): 47-65.

Ahmadi M, Zahir ZA and Khalid M, 2015. Efficacy of Rhizobium and Pseudomonas strains to improve physiology, ionic balance and quality of mung bean under salt-affected conditions on farmer's fields. Plant Physiol. Biochem. 63: 170176.

Aini N, Yamika WSD and Ulum B, 2019. Effect of nutrient concentration, PGPR and AMF on plant growth, yield, and nutrient uptake of hydroponic lettuce. Int. J. Agric. Biol. 21: 175-183.

Ali J, Ali F, Ahmad I, Rafique M, Munis MFH, Hassan SW and Chaudhary HJ, 2021. Mechanistic elucidation of germination potential and growth of Sesbania sesban seedlings with Bacillus anthracis PM21 under heavy metals stress: An in vitro study. Ecotoxicol. Environ. Saf. 208: 111769.

Ali J, Mahmood T, Hayat K, Afridi MS, Ali F and Chaudhary HJ, 2018. Phytoextraction of Cr by maize (Zea mays L.): the role of plant growth promoting endophyte and citric acid under polluted soil. Arch. Environ. Prot. 44(2): 73-82.

Ali S, Sandhya ZV, Grover M, Linga VR and Bandi $\mathrm{V}$, 2011. Effect of inoculation with a thermotolerant plant growth promoting Pseudomonas putida strain AKMP7 on growth of wheat (Triticum spp.) under heat stress. J. Plant
Interact. 6(4): 239-246.

Ali SZ, Sandhya V, Grover M, Kishore N, Rao LV and Venkateswarlu B, 2009. Pseudomonas sp. strain AKM-P6 enhances tolerance of sorghum seedlings to elevated temperatures. Biol. Fert. Soil. 46: 45-55.

Amna, SS, Din B, Xia Y, Kamran MA, Javed MT, Sultan T and Chaudhary HJ, 2019. Mechanistic elucidation of germination potential and growth of wheat inoculated with exopolysaccharide and ACC- deaminase producing Bacillus strains under induced salinity stress. Ecotoxicol. Environ. Saf. 183: 109466.

Asari S, Tarkowská D, Rolčík J, Novák O, Palmero DV, Bejai S and Meijer J, 2017. Analysis of plant growth-promoting properties of Bacillus amyloliquefaciens UCMB5113 using Arabidopsis thaliana as host plant. Planta. 245(1): 15-30.

Ashwini K and Gaurav K, 2011. Optimization, production, and partial purification of extracellular $\alpha$-amylase from Bacillus sp. marini. Arch. Appl. Sci. Res. 3(1): 33-42.

Beinsan C, Camen D, Sumalan $R$ and Babau $M$, 2003. Study concerning salt stress effect on leaf area dynamics and chlorophyll content in four bean local landraces from Banat areas. Fac. Hortic. 119: 416-419.

Batool R, Mazhar R, Javed A, Tehmeena M, Shehzad M, Tariq S and Chaudhary HJ, 2019. Biocontrol potential of Bacillus gibsonii and Brevibacterium frigoritolerans in suppression of Fusarium stalk rot of maize: a sustainable approach. Asian J. Agric. Biol. 7(3): 320-333.

Bauchet $\mathrm{G}$ and Causse M, 2012. Genetic diversity in tomato (Solanum lycopersicum) and its wild relatives. Genetic Divers. Plants. 8: 134-162.

Bita C, Gerats T, 2013. Plant tolerance to high temperature in a changing environment: scientific fundamentals and production of heat stresstolerant crops. Front. Plant Sci, 4: 273.

Chand JB, Hewa G, Hassanli A and Myers B, 2021. Deficit irrigation on tomato production in a greenhouse environment: A review. J. Irrig. Drain. Eng. 147(2): 04020041.

Chandra V, Fetter-Pruneda I, Oxley PR, Ritger AL, McKenzie SK, Libbrecht $\mathrm{R}$ and Kronauer DJC, 2018. Social regulation of insulin signaling and the evolution of eusociality in ants. Sci. 361(6400): 398-402.

de Jong M, Wolters-Arts M, Feron R, Mariani C and 
Vriezen WH, 2009. The Solanum lycopersicum auxin response factor 7 (SlARF7) regulates auxin signaling during tomato fruit set and development. Plant J. 57: 160-170.

Din BU, Rafique M, Javed MT, Kamran MA, Mehmood S, Khan M and Chaudhary HJ, 2020. Assisted phytoremediation of chromium spiked soils by Sesbania Sesban in association with Bacillus xiamenensis PM14: A biochemical analysis. Plant Physiol. Biochem. 146: 249-258.

Dinesh R, Anandaraj M, Kumar A, Bini YK, Subila $\mathrm{KP}$ and Aravind R, 2015. Isolation, characterization, and evaluation of multi-trait plant growth promoting rhizobacteria for their growth promoting and disease suppressing effects on ginger. Microbiol. Res.173: 34-43.

Dodd IC, Egea G, Watts CW and Whalley WR, 2010. Root water potential integrates discrete soil physical properties to influence ABA signaling during partial rootzone drying. J. Exp. Bot. 61: 3543-3551

Duan J, Müller KM, Charles TC, Vesely S, and Glick BR, 2009. 1-aminocyclopropane-1-carboxylate (ACC) deaminase genes in rhizobia from southern Saskatchewan. Microbial Ecolol. 57(3): 423-436.

Efeoğlu B, Ekmekçi Y and Çiçek N, 2009. Physiological responses of three maize cultivars to drought stress and recovery. South Afr. J. Bot. 75(1): 34-42.

Fahad S and Bano A, 2012. Effect of salicylic acid on physiological and biochemical characterization of maize grown in saline area. Pak. J. Bot. 44: 1433-1438.

Fahad S, Nazir U, Anjum S A, Farooq A and Zohaib A, 2017. Crop production under drought and heat stress: plant responses and management options. Front. Plant Sci. 8:1147.

Faiza S, Hafiz NA, Zain M, Amina H, Naqshe Z, Rizwan A and Muhammad AA, 2020. Role of endomycorrhizae, rhizobacteria and compost to improve phosphorus availability in onion. Asi, J. Agric Biol. 8(2): 194-200.

Grover M, Ali V, Sandhya SZ and Venkateswarlu B, 2011. Role of microorganisms in adaptation of agricultural crops to abiotic stresses. World J. Microbiol. Biotechnol. 27:1231-1240

Greer DH and Weedon MM, 2011. Modelling photosynthetic responses to temperature of grapevine (Vitis vinifera cv. Semillon) leaves on vines grown in a hot climate. Plant Cell. Environ.
35(6): 1050-1064

Gupta VK, Agarwal S, Singh P and Pathania D, 2012. Acrylic acid grafted cellulosic luffa cylindrical fiber for the removal of dye and metal ions. Carbohydr. Polym. 98:1214-1221.

Hussain HA, Men S and Hussain S, 2019. Interactive effects of drought and heat stresses on morphophysiological attributes, yield, nutrient uptake and oxidative status in maize hybrids. Sci. Rep. 9: 3890.

Jung S, Kim JS, Cho KY, Tae GS and Kang BG, 2000. Antioxidant responses of cucmber (Cucumis sativus) to photoinhibition and oxidative stress induced by norflurazon under high and low PPFDs. Plant Sci. 153: 145-154.

Kamara AY, Menkir A, Badu-Apraku B and Ibikunle $\mathrm{O}, 2003$. The influence of drought stress on growth, yield and yield components of selected maize genotypes. J. Agric. Sci. 141:43-50.

Kapoor R, Soni R, and Kaur M, 2016. Gibberellins production by fluorescent Pseudomonas isolated from Rhizospheric soil of Malus and Pyrus. Int. J Agric, Environ Biotechnol, 9(2): 193-199.

Khan MIR and Khan NA, 2014. Ethylene reverses photosynthetic inhibition by nickel and zinc in mustard through changes in PSII activity, photosynthetic nitrogen use efficiency, and antioxidant metabolism. Protoplasma. 51: 10071019.

Khan MA, Asaf S, Khan AL, Jan R, Kang SM, Kim $\mathrm{KM}$ and Lee IJ, 2020. Extending thermotolerance to tomato seedlings by inoculation with SA1 isolate of Bacillus cereus and comparison with exogenous humic acid application. PLoS One, 15(4): e0232228.

Liu F, Xing S, Ma H, Du Z and Ma B, 2013. Cytokinin-producing, plant growthpromoting

Rhizobacteria Cteria that confer resistance to drought stress in Platycladus orientalis container seedlings. Appl. Microbiol. Biotechnol. 97(20): 9155-9164.

Louden BC, Haarmann D and Lynne AM, 2011. Use of blue agar CAS assay for siderophore detection. J. Microbiol. Biol. Educ. 12 (1): 51-53

Maqbool S, Amna A, Mehmood S, Suhaib M, Sultan $\mathrm{T}$ and Munis MFH, 2021. Interaction of Acc Deaminase and Antioxidant Enzymes To Induce Drought Tolerance In Enterobacter Cloacae 2wc2 Inoculated Maize Genotypes. Pak. J. Bot. 53: 28. DOI:10.30848/PJB2021-3(28). 
Mehmood S, Khan AA, Shi F, Tahir M, Sultan T, Munis MFH and Chaudhary HJ, 2021. Alleviation of Salt Stress in Wheat Seedlings via Multifunctional Bacillus aryabhattai PM34: An In-Vitro Study. Sustainability. 13(14): 8030.

Mukhtar A, Manzoor M, Gul I, Zafar R, Jamil HI, Niazi AK, Ali MA, Park TJ and Arshad M, 2020a. Phytotoxicity of different antibiotics to rice and stress alleviation upon application of organic amendments. Chemosphere. 258: 127353

Mukhtar T, Smith D, Sultan T, Seleiman MF, Alsadon AA, Ali S, Saad MA, 2020b. Mitigation of heat stress in Solanum lycopersicum L. by ACC-deaminase and exopolysaccharide producing Bacillus cereus: effects on biochemical profiling. Sustainability, 12(6): 2159.

Muneer MA, Wang P, Zhang J, Li Y, Munir MZ and Ji B, 2020a. Formation of common mycorrhizal networks significantly affect plant biomass and soil properties of the neighboring plants under various nitrogen levels. Microorganisms. 8: 230.

Muneer MA, Wang P, Lin C and Ji B, 2020b. Potential role of common mycorrhizal networks in improving plant growth and soil physicochemical properties under varying nitrogen levels in a grassland ecosystem. Glob. Ecol. Conserv. 24: 01352.

Nadeem SM, Ahmad M, Zahir ZA, Javaid A, Ashraf $M, 2014$. The role of mycorrhizae and plant growth promoting rhizobacteria (PGPR) in improving crop productivity under stressful environments. Biotechnol. Adv. 32(2): 429-448.

Nadeem SM and Imran M, 2017. Synergistic use of biochar, compost, and plant growth promoting rhizobacteria for enhancing cucumber growth under water deficit conditions. J. Sci. Food Agric. 97(15): 5139-5145.

Naseem H and Bano A, 2014. Role of plant growthpromoting rhizobacteria and their exopolysaccharide in drought tolerance of maize. J. Plant. Interact. 9(1): 689-701.

Noonari S, Memon MIN, Solangi SU, Laghari MA, Wagan SA, Sethar AA and Panhwar GM, 2018. Economic Implications of Tomato Production in Naushahro Feroze District of Sindh Pakistan. Int. J. Agric. Ext. Rural Develop. Stud. 2(2):19-28.

Pandey S and Gupta S, 2019. ACC deaminase producing bacteria with multifarious plant growth promoting traits alleviates salinity stress in French bean (Phaseolus vulgaris) plants. Front. Microbiol. 10: 1506.

Ruelland E and Zachowski A, 2010. How plants sense temperature. Environ. Exp. Bot: 69(3): 225-232.

Tiru M, Muleta D, Bercha G and Adugna G, 2013. Antagonistic effect of rhizobacteria against coffee wilt disease caused by Gibberella xylarioides. Asian. J. Pathol. 7: 109-122.

Wahid AA, Gelani S, Ashraf $M$ and Foolad M, 2007. Heat tolerance in plants: An overview. Environ. Exp. Bot. 61(3): 199-223.

Wang $M$ and Riffel M, 2011. Making the right conclusions based on wrong results and small sample sizes: interpretation of statistical tests in ecotoxicology. Ecotoxicol. Environ. Saf. 74(4): 684-692.

Yasmin $H$ and Bano A, 2011. Solation and characterization of Phosphate solubilizing bacteria from rhizosphere soil of weeds of Khewra Salt range and Attock. Pak. J. Bot. 43(3): 1663-1668.

Zahir ZA, Munir A, Asghar HN, Shaharoona B and Arshad M, 2008. Effectiveness of rhizobacteria containing ACC-deaminase for growth promotion of pea (Pisum sativum) under drought conditions. J. Microbiol. Biotechnol. 18: 958-963.

Zainab N, Din BU, Javed MT, Afridi MS, Mukhtar T, Kamran MA and Chaudhary HJ, 2020. Deciphering metal toxicity responses of flax (Linum usitatissimum L.) with exopolysaccharide and ACC-deaminase producing bacteria in industrially contaminated soils. Plant Physiol. Biochem. 152: 90-99

\section{Contribution of Authors}

Mukhtar T: Data collection and manuscript writing

Rehman SU: Data interpretation and manuscript revision

Sultan T: Data collection and analysis

Munis FH: Designed research methodology and literature review

Chaudhary HJ: Conceived idea and manuscript final approval 